v.9, n. 1

Vitória-ES, jan - mar 2012

p. 125-145 ISSN 1808-2386 DOI: http://dx.doi.org/10.15728/bbr.2012.9.1.6

\title{
Antecedents for defining management control system design: empirical evidence from Brazilian firms
}

\author{
Fábio Frezatti ${ }^{\dagger}$ \\ University of São Paulo \\ Emanuel Junqueira \\ Espírito Santo Federal University \\ Diógenes de Souza Bido ${ }^{\ddagger}$ \\ Mackenzie Presbyterian University \\ Artur Roberto do Nascimento $\ddagger$ \\ Feira de Santana State University \\ Tânia Regina Sordi Relvas $\Theta$ \\ University of São Paulo
}

\begin{abstract}
This work analyzes the development profile of Brazilian firms regarding management accounting attributes. Much has been written in recent years about the design of management control systems and the use of management control artifacts, but there is a relevant antecedent that has been little explored, namely the profile of these attributes, involving aspects such as scope, timeliness, integration and aggregation (Chenhall \& Morris, 1986; Silvola, 2008). These attributes define, limit and expand the power for management control to act (Berry, Broadbent \& Otley, 2005) and they are interdependent, since each influences the others. They are the basis on which the organization's management model is structured and developed. Within the universe of a firm's management control, there are various artifacts that are implemented with the aim of providing support to managers' decision-making process, besides coordination and
\end{abstract}

Received on 11/29/2010; reviewed on 08/18/2011; accepted on 09/13/2011; available in 03/05/2012

Correspondência autores*:

\begin{tabular}{|c|c|c|c|}
\hline $\begin{array}{l}{ }^{*} \text { Associate Professor at } \\
\text { USP } \\
\text { Address: Av.Prof. } \\
\text { Luciano Gualberto, } \\
\text { 908, FEA 3, sala 226, } \\
\text { São Paulo - SP - Brazil } \\
\text { E-mail:frezatti@ @ usp.br } \\
\text { Telephone: (11) } \\
\text { 30915820 - r } 157\end{array}$ & $\begin{array}{l}{ }^{\Omega} \text { Ph.D. in } \\
\text { Accounting from } \\
\text { USP. } \\
\text { Professor of UFES } \\
\text { Address: Rua } \\
\text { Constante Sodré, } \\
\text { 869/1001 - Praia do } \\
\text { Canto, Vitória - ES } \\
\text { - Brazil } \\
\text { E-mail: } \\
\text { emanuel.junqueira@ } \\
\text { gmail.com } \\
\text { Telephone: (27 ) } \\
\text { 4009-7700 }\end{array}$ & $\begin{array}{l}\text { ¥ Doctor of Business } \\
\text { Administration from } \\
\text { USP. } \\
\text { Adjunct Professor at the } \\
\text { University Mackenzie } \\
\text { Address: Av. Santo } \\
\text { Antônio, } 472 \text { - Vila } \\
\text { Osasco - Osasco - SP - } \\
\text { Brazil } \\
\text { E-mail: } \\
\text { diogenesbido@ yahoo.co } \\
\text { m.br } \\
\text { Telephone: (11)3681- } \\
\text { 5780 }\end{array}$ & $\begin{array}{l}\text { ¥ PhD in } \\
\text { Accounting and } \\
\text { Accounting from } \\
\text { USP. } \\
\text { Assistant Professor, } \\
\text { State University of } \\
\text { Feira de Santana. } \\
\text { Address: Avenida } \\
\text { Transordestina, Novo } \\
\text { Horizonte, Feira de } \\
\text { Santana - BA - } \\
\text { Brazil } \\
\text { E-mail: } \\
\text { artnascimento@gmail } \\
\frac{\text { com }}{\text { Telephone: (75) }} \\
31618052\end{array}$ \\
\hline
\end{tabular}

$\Theta$ PhD from USP. Professor at USP Universidade de São Paulo.

Address: Avenida Marechal Eurico Gaspar Dutra, 988 Jardim São Paulo, São Paulo - SP - Brazil E-mail: taniarsr@usp.br Telephone: (11) 3091 5820, ramal 166

Nota do Editor: Esse artigo foi aceito por Antonio Lopo Martinez.

Esta obra está licenciada sob a Licença Creative Commons - Atribuição-Uso não-comercial-Compartilhamento pela mesma licença 3.0 Unported License 
influence on the employees (Anthony \& Govindarajan, 2002; Hansen \& Mouritsen, 2007). Among the existing artifacts cited in the literature as relevant for the planning and control process are strategic planning, budgeting, capital budgeting, profitability analysis, rolling forecasting and real options. In a changing environment, the attributes can change in terms of form and amplitude, demand and utilization, implying the need for integrated and proactive review and adjustment. The impact of the adequacy of these attributes on the design and use of management control systems is so relevant that they can distort and impair this design and use. To address the theme within a consistent theoretical framework, the idea of attribute in this article is based on some classic works (Chenhall \& Morris, 1986; Silvola, 2008). This is a descriptive study, developed from an exploratory perspective, looking ahead to more comprehensive development in the future, given the absence of analogous works on Brazilian firms. The study was carried out through a survey of a sample composed of 125 Brazilian firms, with the data gathered by a structured questionnaire administered over the Internet. The data were analyzed by partial least squares path modeling (PLS-PM). The results suggest that the attributes examined are related in different ways, depending on the profile of the organization's scope, influencing the existence of some management accounting artifacts, which should be taken into account in defining or updating the management information system. In short, if a firm wants to use artifacts for management control, it should review the structuring of its attributes.

Key words: Management control; development of Brazilian companies 


\section{INTRODUCTION}

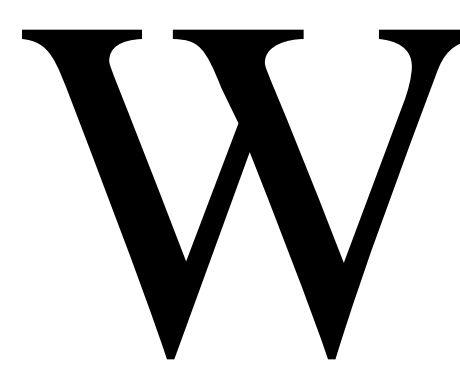

hy speak of antecedents? Because often some requirements that should be considered in examining a given theme undergo changes, including in importance of their configuration. Relevant aspects for investigating a theme can cease to be important due to changes in the environment or technology or the emergence of substitutes. When reexamining antecedents, it is necessary to review the structural base and constructs, and in this process opportunities for organizational improvement arise.

In the present case, the antecedents are the structure of the management control system and its attributes (scope, timeliness, aggregation and integration). Although they are present in all organizations, the change that comes over time can cause certain aspects to be overlooked because their review is not valorized. In the final analysis, to change and progress it is often necessary to review and rethink pillars previously considered as solid and untouchable.

Management of organizations requires an information system that provides responses to the demands of users of accounting. This system is traditionally separated into two areas of study: financial accounting, which involves the information for external users, and management accounting, which deals with the information intended for internal use of the organization (Hansen \& Mowen, 1997, p. 2). The study of management accounting is mainly concerned with: (i) supporting firms' decision-making process (Anthony \& Govindarajan, 2002), and (ii) influencing and (iii) coordinating people (Hansen \& Mouritsen, 2007).

In turn, within the management process, management control "is a process of guiding organizations into viable patterns of activity in a changing environment” (Berry, Broadbent \& Otley, 2005, p. 18). That process cannot subsist without a management accounting system that is structured consistently with the demands, and should provide conditions to instigate, orient and clarify managers regarding the important elements for managing their organization.

For this to occur, the information system developed must be dynamic, regarding currency, flexibility, amplitude and diversification. However, the limit on the potential use is intrinsically related to the system's capacity and the manager's demand. 
While in theory a firm that has the latest management instruments should obtain better results, this has not been empirically demonstrated (Chenhall, 2003, p. 132).

A firm's financial result depends on a series of management aspects, and the use of management accounting resources can at most make managers more prepared and more confident to perform their activities, besides more assertive due to the support of the process. Therefore, achieving better financial results depends on a complex combination of many internal and external factors that are very hard to identify and study. In this way, the existence of an information structure results from the belief that assertiveness improves the quality of management.

In this sense, one antecedent of the existence of artifacts (the management control techniques that will be employed) is the design of the management information system. And in turn, a forerunner of the management information system's design is the presence of determined qualitative aspects, called attributes, of the management accounting system. These regulate the scope and characteristics of the information provided. The attributes are the scope, timeliness, integration and aggregation of the system.

Weak and unambitious attributes in terms of scope imply limited designs to meet the demand for artifacts. To some extent the attributes can interact, influencing each other. Alterations in the configuration of the attributes are certainly possible, but need to be consistent among the elements, without which the artifacts will not meet the demand or will do so only partly.

The importance of studying the attributes of the management control system rests in the fact that the choice of the characteristics of the information generated by the system (the system's attributes) are forerunners for development of the system and the choices of the artifacts that compose it.

Therefore, adequate knowledge of the antecedents for developing the management control system can enable artifacts to be developed and implemented in harmony with the needs of the particular firm.

Awareness of this condition allows avoiding wasted effort by the people involved and increases the efficiency and efficacy of the system, in the sense of contributing more decisively to the firm's competitiveness and profitability. In turn, these aspects potentially mean more employment and wealth for the country as a whole. As a consequence of these observations, our guiding research question can be stated as follows: Is there an association between the attributes of management control systems (scope, timeliness, 
aggregation and integration) and the profile of the artifacts of management information systems?

\section{LITERATURE REVIEW}

The basic elements to study the theme are: (i) evolution of the attributes, (ii) design of the management control system and (iii) management control artifacts.

\subsection{Evolution of the attributes}

Chenhall \& Morris (1986), in a seminal article, present the attributes of management information systems: scope, timeliness, integration and aggregation. These attributes are essential to the design and use of management control systems and permit identifying their profile.

Regarding scope, which refers to focus, quantification and horizon (Chenhall \& Morris, 1986), the authors indicate that different dimensions are possible: narrow, broad or intermediate, also called medium (Silvola, 2008).

The broad dimension should provide (i) internal and external information, (ii) financial and nonfinancial information, and (iii) information oriented to the past and the future.

Restricted scope means the information is more limited, basically involving internal historic and financial information. This information will have to be adjusted in relation to timeliness, aggregation and integration to allow balance in the management information system design.

According to Silvola (2008), there is an intermediate profile, which differs from the broad scope only by not including external information.

Scope should be the first attribute to be defined, and consequently the entire design of the management information system should depend of its amplitude. However, this may not happen in practice, because definition of the design occurs at a certain moment and in the future may not meet the information demands in a properly organized and holistic form, unless efforts are made to revise the system's attributes in relation to the current configuration and complexity of operations.

Timeliness is defined in terms of opportune response, that is, providing information when requested or in the frequency desired. It enhances the use of management information, providing rapid feedback to the decisions made. The timely availability of 
information is a relevant factor, and although the supply of historic information may not be so complicated, the supply of projected information about the future, for example detailed by business unit, is more complex and costly. Automation plays an important role in the generation and availability of information in standardized form, and if a firm's computer systems are not up to the task, timely use of information will not be possible, making for inefficient management.

Aggregation is the attribute that permits information to be offered at various levels of agglutination, from simple information considered basic, such as the amount of a raw material not yet processed, to information aggregated in various time periods or by cost centers or areas of interest, etc. Proper aggregation can bring relevant responses for management actions. To achieve this requires analysis and decisions in terms of relevance and priorities. Obviously, changes in the modus operandi and structural changes, such as mergers and acquisitions, demand comprehensive revisions.

Finally, integration entails the coordination of various segments within a firm or business unit/area. This may simply involve combining information on areas over time or it can involve internal transfer prices, acting to regulate the relationship between different units, revealing their interdependence. In other words, integration refers to the information about the operations and activities of the units of an organization and also information about the impact of one unit's decisions on the performance of the others (Bouwens \& Abernethy, 2000) and of the organization as a whole.

Moores \& Yuen (2001), revisiting approaches covered before (Merchant, 1981, 1997), refer to attributes as being the formality of routines and procedures with intensive use of computers, the technical team and financial modeling, all of which must have certain characteristics to be selected and presented within the decision process. Therefore, the prior choice of these attributes, regarding the structuring or fit of the design of management control systems implies identification of the qualities that managers expect from the information provided by the system.

\subsection{Management information system designs}

Aguiar \& Frezatti (2007) describe the development of management information system models based on DeLone \& McLean (1992), whose approach had the merit of combining qualitative aspects with a set of elements. It has become known as the taxonomy of DeLone \& McLean (1992), which contains six dimensions analyzed to reach conclusions on the success of an information system. 
These dimensions are: (i) system quality, with focus on the definitions of the desired characteristics of the information system; (ii) information quality, which defines the information to be provided by the information system and its quality; (iii) use, meaning the way the system is utilized; (iv) user satisfaction, which considers the attitudes of managers regarding the system; (v) individual impact, which analyzes the perception of individual users, their understanding of the information received and the change this causes in decision behavior; and (vi) organizational impact, which considers the influence that the individual impact has on the organization and the impact of the individual decisions on the organization (Delon \& McLean, 1992; Iivari, 2005).

The management information system attributes are included in the information quality category. In the approach of DeLone \& McLean (1992), the system's success depends on the balance, or at least the consistency and coherence, among all six dimensions.

Seddon (1997) starts from the model of DeLone \& McLean and also criticizes its qualitative potential, which can cause confusion. As a solution, he proposes the inclusion of new variables in the model: (i) expectations of decision-makers about the costs and benefits of future use of the information system; (ii) corporate (shareholders), organizational and individual consequences of the results attributed to the system's use; (iii) perceived utility, which is an indicator of how strongly managers believe that the use of a particular information system will have on their performance or that of the group or organization, by producing benefits; and (iv) net benefits, measuring the sum of all the past benefits and the expected future ones attributed to the use of an application of the system, as perceived by the shareholders.

The contribution of Moores \& Yuen (2001) to management information system models was to include segmentation between different levels of formality regarding the nature of the selection and presentation of management accounting information over the life cycle of companies. They use a life cycle perspective to discriminate this model. In their framework, the attributes of management information systems are found in the presentation of the information.

Henri (2006) presents a configuration that considers aspects regarding the diversity of the indicators: (i) subjectivity and objectivity, (ii) internal and external focus and (iii) financial and nonfinancial metrics; as well as regarding the nature of use: (i) monitoring, (ii) attention focusing and (iii) strategic decision-making legitimization. 
Ferreira \& Otley $(2006 ; 2009)$ make an important contribution by including cost as an attribute, as well as, based on the work of Simons (1990; 1995), incorporating a use dimension that includes the way managers use information: (i) diagnostic use (monitoring performance to take corrective actions), (ii) interactive use (monitoring strategic uncertainties and permitting dialog between mangers and subordinates) and (iii) dysfunctional use (use for purposes other than those envisioned for diagnostic or interactive use).

Besides the characteristics of the information that will be provided, the design of the management control system depends on decisions about the artifacts that will integrate it (techniques utilized), which can be classified as traditional and contemporary (Chenhall \& Langfield-Smith, 1998; Otley, 1999; Ferreira \& Otley, 2006).

In this respect, besides the design, the proposal incorporates the use perspectives of Simons $(1990 ; 1995)$, so that management control systems can be understood in relation to two dimensions (Figure 1), one involving the design and the other the use (Ferreira \& Otley, 2006; 2009).

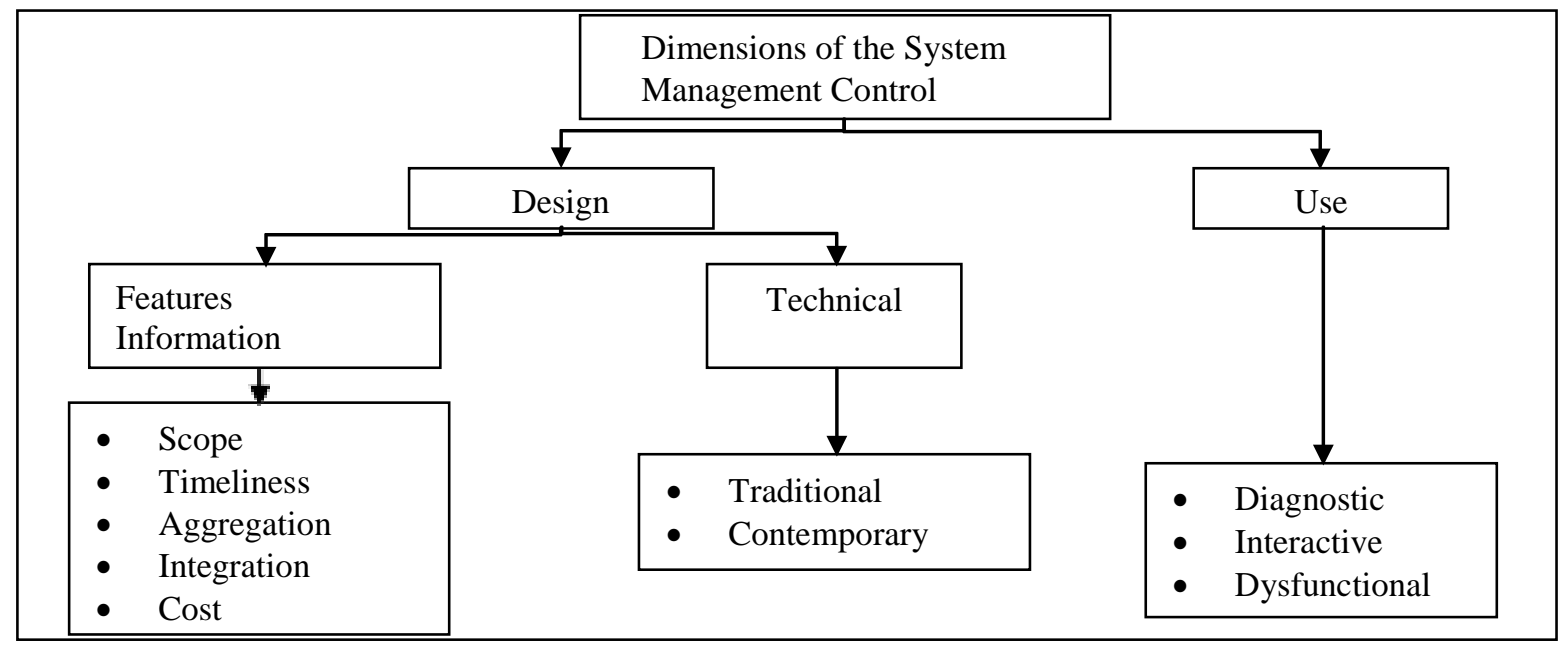

Figure 1 - Management information system dimensions

Source: Aguiar \& Frezatti (2007), illustrating the model of Ferreira \& Otley (2006).

Despite the interdependence of these two dimensions, our basic element in this study is the performance of the design of the management control system. Additionally, we treat this design solely in terms of the characteristics of the information produced by it (attributes of the management control system), rather than in terms of the practices employed (management control artifacts or techniques).

As can be seen from the above discussion, attributes are included in all the models, being defined as qualitative factors that affect the system as a whole. Therefore, study of 
the attributes, from the perspective of antecedents for development of the system, becomes the main backdrop, independent of its design and hence use.

\subsection{Management control artifacts}

Artifacts are the carriers of institutional values, products of human actions: hardware, software, technologies or ideas (Scott, 2001, p. 81).

From the standpoint of management control, artifacts correspond to all the instruments and techniques employed to support management of firms. An artifact can be a concept, a system, a method or a tool (Frezatti et al., 2009). The existence and use of artifacts should improve the chances of organizational success, and this requires consumption of resources (money, time, equipment, training, etc.) that will not be avaialable for alternative uses.

Chenhall \& Langfield-Smith (1998) and Ferreira \& Otley (2006) indicate the following set of management control artifacts: formal strategic planning, balanced scorecard, traditional annual budgeting, beyond budgeting, rolling forecasting, capital budgeting, activity-based management (ABM), life-cycle analysis, product profitability analysis, customer and market analysis, value chain analysis, quality improvement programs, application of real options to analyze investment projects, operational research techniques, variable costing, direct costing, absorption costing, target costing, internal and external benchmarking and economic value added (EVA) analysis.

However, not all these artifacts are considered here. Out criteria for selecting the artifacts were: (i) recognition as an instrument of some part of formal planning; (ii) greater relative security that the essence of the artifact was captured by the survey among the respondents; and (iii) elements that permit avoiding the perspectives of "is contained or contains" (e.g., EVA can exist by itself in the firm's analysis or it can be present in more than one artifact, such as strategic planning, budgeting or capital budgeting).

Therefore, from the list provided by Chenhall \& Langfield-Smith (1998), we surveyed formal strategic planning, traditional annual budgeting, rolling forecasting, capital budgeting, product profitability analysis, customer and market analysis and real options to analyze investment projects. 


\section{RESEARCH DESIGN}

The research design took into account the relationship between the four management accounting system attributes and the six management control artifacts

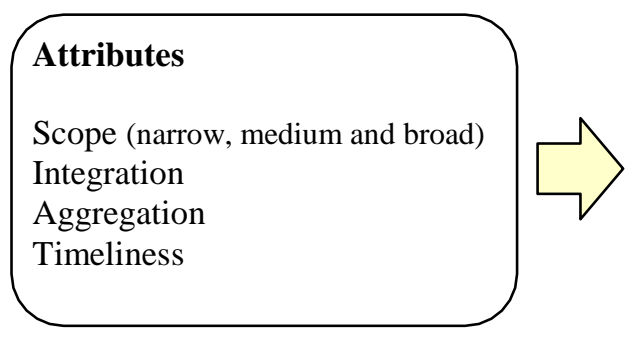

Figure 2: Research design
Artifacts

Formal strategic planning

Traditional annual budgeting

Rolling forecasting

Capital budgeting

Profitability analysis of products, customers and markets

Real options to analyze investment projects

The literature has addressed the attributes, but without exploring the way they are interrelated or whether or how they relate with the artifacts.

\section{Nature of the study}

In light of the need for more information for a better understanding of the theme with respect to Brazilian firms, this is a descriptive study with a quantitative approach that aims to identify, based on primary data, the aspects of real importance to the theme, even though for the sample considered questions with descriptive characteristics can be found. The results can serve as elements for future studies.

\section{Population}

The population includes listed and unlisted companies established in Brazil, with both national and foreign ownership, including state-controlled ones. The data on these firms was obtained from the 2006 edition of Melhores \& Maiores ("Best \& Biggest"), referring to 2005, considering medium and large companies. The size classification is based on the definition of the National Bank for Economic and Social Development (BNDES, Circular 64/2002), according to which a medium company is one with annual revenue above $\mathrm{R} \$ 10.5$ million and large ones as those with revenue greater than $R \$ 60$ million, although not targeted in the analysis of this work.

\section{Sample and data collection}

We collected the data via the Internet, using the Formsite tool, by applying a semiopen questionnaire. The reason for choosing this type of questionnaire was its adequacy in terms of scope and objectivity. We addressed the questionnaires to the chief financial officer or the executive in charge of investor relations. 
The stratification was based on sector and size (in terms of annual revenue). The distribution found in terms of turnover was relatively balanced. However, out of the 24 different sectors used by the magazine to classify the companies, we formed 19 groups (sectors), within a criterion of maximum homogeneity, due to the great dispersion in some sectors (Table 1).

The sample of firms was composed by using a probabilistic approach, based on random numbers. Once the sample size was determined, the firms were drawn within the stratification chosen. In the case of firms that did not answer the questionnaire, a new drawing was carried out to replace them. Of a total of 2,181 companies (population), the final sample was made up 125 companies.

Table 1 Segmentation of the sample

\begin{tabular}{|c|c|c|c|c|c|c|c|c|c|}
\hline \multirow[b]{2}{*}{ Sectors } & \multicolumn{7}{|c|}{ Ranges of revenues (in milions) } & \multirow[b]{2}{*}{ Total } & \multirow{2}{*}{$\begin{array}{l}\% \text { of } \\
\text { total }\end{array}$} \\
\hline & $<\mathbf{5 0}$ & $\begin{array}{c}>50<1 \\
00 \\
\end{array}$ & $\begin{array}{c}>100< \\
250 \\
\end{array}$ & $\begin{array}{c}>250< \\
500 \\
\end{array}$ & $\begin{array}{c}>500<1 \\
000\end{array}$ & $\begin{array}{c}>1.000<3 \\
.000 \\
\end{array}$ & $\begin{array}{c}>3.0 \\
00\end{array}$ & & \\
\hline Agribusiness & 0 & 0 & 1 & 1 & 0 & 2 & 0 & 4 & $3,2 \%$ \\
\hline Food, beverage and tobacco & 2 & 1 & 2 & 1 & 1 & 0 & 0 & 7 & $5,6 \%$ \\
\hline $\begin{array}{l}\text { Wholesale, retail and foreing } \\
\text { trade }\end{array}$ & 1 & 1 & 2 & 0 & 4 & 1 & 1 & 10 & $8,0 \%$ \\
\hline Cars and trucks & 1 & 2 & 0 & 0 & 3 & 1 & 2 & 9 & $7,2 \%$ \\
\hline Apparel and Textile & 0 & 0 & 0 & 2 & 2 & 0 & 1 & 5 & $4,0 \%$ \\
\hline Civil construction & 0 & 3 & 0 & 1 & 1 & 0 & 0 & 5 & $4,0 \%$ \\
\hline Eletroeletronics & 1 & 1 & 1 & 2 & 0 & 0 & 0 & 5 & $4,0 \%$ \\
\hline Energy & 2 & 0 & 0 & 0 & 1 & 0 & 0 & 3 & $2,4 \%$ \\
\hline $\begin{array}{l}\text { Pharmaceutical, cosmetics } \\
\text { and toiletries }\end{array}$ & 1 & 1 & 0 & 0 & 2 & 4 & 1 & 9 & $7,2 \%$ \\
\hline Financial Institutions & 1 & 0 & 0 & 2 & 3 & 0 & 3 & 9 & $7,2 \%$ \\
\hline Chemical and petroquemical & 2 & 0 & 1 & 2 & 0 & 2 & 1 & 8 & $6,4 \%$ \\
\hline Utilities & 0 & 1 & 2 & 0 & 3 & 1 & 0 & 7 & $5,6 \%$ \\
\hline Siderurgy and metalurgy & 2 & 1 & 1 & 0 & 1 & 1 & 2 & 8 & $6,4 \%$ \\
\hline Technology and computers & 1 & 0 & 1 & 1 & 3 & 1 & 0 & 7 & $5,6 \%$ \\
\hline Telecommunications & 0 & 0 & 1 & 1 & 0 & 0 & 1 & 3 & $2,4 \%$ \\
\hline Transport and logistics & 1 & 1 & 0 & 1 & 0 & 0 & 0 & 3 & $2,4 \%$ \\
\hline Other industries & 3 & 1 & 2 & 1 & 1 & 1 & 0 & 9 & $7,2 \%$ \\
\hline Other Services & 0 & 3 & 1 & 0 & 0 & 0 & 0 & 4 & $3,2 \%$ \\
\hline All others & 2 & 2 & 1 & 2 & 1 & 1 & 1 & 10 & $8,0 \%$ \\
\hline Total & 20 & 18 & 16 & 17 & 26 & 15 & 13 & 125 & $\begin{array}{c}100,0 \\
\%\end{array}$ \\
\hline$\%$ of total & $\begin{array}{c}16,0 \\
\% \\
\end{array}$ & $\begin{array}{c}14,40 \\
\%\end{array}$ & $\begin{array}{c}12,80 \\
\%\end{array}$ & $\begin{array}{c}13,60 \\
\%\end{array}$ & $20,80 \%$ & $12,00 \%$ & $\begin{array}{c}10,40 \\
\%\end{array}$ & $\begin{array}{c}100,0 \\
0 \% \\
\end{array}$ & \\
\hline
\end{tabular}




\section{Variables of interest and scale}

The variables significant for the study resulted from the research design, regarding the attributes (Table 2) and artifacts (Table 4).

\section{Analysis of the data}

We used the following statistical treatment:

Univariate analysis: frequency analysis.

Bivariate analysis: correlations between the attributes and artifacts.

Dultivariate analysis: Measurement and structural models, estimated simultaneously by partial least squares path modeling (PLS-PM), which we considered most suitable for our research objectives because it has a predictive aim, is indicated in studies that are more exploratory than comfirmatory (tests of theories) and is also able to deal with small samples (fewer than 200 cases) (Zwicker et al., 2008).

\section{RESULTS AND DISCUSSION}

The analysis was conducted in the following sequence: (i) the set of attributes, (ii) the set of artifacts, and (iii) the relation of the artifacts and the different scope profiles.

\subsection{Attributes}

Approximately half of the firms investigated use some attribute, as shown in Table 2.

Table 2: Attribute use frequencies

\begin{tabular}{llcc}
\hline Attributes & \multicolumn{1}{c}{ Items used to measure the attribute (a) } & $\begin{array}{c}\text { Number } \\
\text { (yes) }\end{array}$ & \% \\
\hline \multirow{2}{*}{ Scope } & $\begin{array}{l}\text { Internal scope (the information is exclusively intended } \\
\text { for internal questions of the firm) } \\
\text { External scope (the information is aimed at external }\end{array}$ & 69 & $55 \%$ \\
& $\begin{array}{l}\text { users) } \\
\text { Financial (exclusively financial information) }\end{array}$ & 70 & $56 \%$ \\
& $\begin{array}{l}\text { Nonfinancial information included in the analysis } \\
\text { (non-monetary indicators of other natures) }\end{array}$ & 73 & $58 \%$ \\
& $\begin{array}{l}\text { Historic information (real) } \\
\text { Information about the future (projections) }\end{array}$ & 101 & $81 \%$
\end{tabular}




\begin{tabular}{|c|c|c|c|}
\hline Attributes & Items used to measure the attribute (a) & $\begin{array}{c}\text { Number } \\
\text { (yes) }\end{array}$ & $\%$ \\
\hline Aggregation & $\begin{array}{l}\text { Combination of data by functional areas (by cost } \\
\text { centers, business units, etc.) }\end{array}$ & 100 & $80 \%$ \\
\hline \multirow{4}{*}{ Timeliness } & The reports are provided quickly & 72 & $58 \%$ \\
\hline & The standard reports are provided automatically & 59 & $47 \%$ \\
\hline & $\begin{array}{l}\text { The frequency of the reports is according to need } \\
\text { (daily, monthly, etc.) }\end{array}$ & 91 & $73 \%$ \\
\hline & $\begin{array}{l}\text { Information is received practically automatically } \\
\text { (small time lag in receiving information) }\end{array}$ & 36 & $29 \%$ \\
\hline \multirow{3}{*}{ Integration } & $\begin{array}{l}\text { Decision models (break-even point, linear } \\
\text { programming, etc.) }\end{array}$ & 62 & $50 \%$ \\
\hline & $\begin{array}{l}\text { Combination by areas over time (accounting system } \\
\text { accrues balances by area) }\end{array}$ & 43 & $34 \%$ \\
\hline & $\begin{array}{l}\text { Reports of interactions between sub-units (transfer } \\
\text { prices, analysis by sub-unit, etc.) }\end{array}$ & 48 & $38 \%$ \\
\hline
\end{tabular}

Note (a): The scale for all the items is binary (No $=0$ and Yes $=1$ ).

In the structural model, all the attributes were predictors of all the artifacts (the results are commented on in Section 4.3). The estimation was done by partial least squares path modeling (PLS-PM) and the model to measure the four attributes was evaluated in three forms (Table 3):

- Convergent validity: aggregation, integration and timeliness had average extracted variance (AEV) near 0.5, which is the threshold value recommended by Fornell \& Larcker (1981), but the scope had a value below the recommended minimum. Despite this, we continued the analyses, in light of the findings of other studies (Chenhall \& Morris, 1986) and the other results of validity and reliability.

- Discriminant validity: Table 3 shows that the square root of the mean extracted variance (figures in the diagonal) is higher than the correlations between the latent variables. This is an indicator of the presence of discriminant validity (Fornell \& Larcker, 1981).

- Reliability: For the four latent variables, the compound reliability was 0.7 , which is considered acceptable (Fornell \& Larcker, 1981). 
Table 3: Correlation between the attributes and evaluation of the validity and reliability

\begin{tabular}{lcccccccc}
\hline \multicolumn{1}{c}{ Attribute (a) } & AEV & C.R. & Mean (b) & S.D. & $\mathbf{1}$ & $\mathbf{2}$ & $\mathbf{3}$ & $\mathbf{4}$ \\
\hline 1 - Aggregation & 1 & 1 & 0.80 & 0.40 & $\mathbf{1 . 0 0}$ & & & \\
2 - Scope & 0.32 & 0.73 & 0.58 & 0.27 & 0.32 & $\mathbf{0 . 5 6}$ & & \\
3 - Integration & 0.46 & 0.71 & 0.40 & 0.33 & 0.23 & 0.47 & $\mathbf{0 . 6 8}$ & \\
4 - Timeliness & 0.46 & 0.77 & 0.52 & 0.32 & 0.18 & 0.47 & 0.35 & $\mathbf{0 . 6 8}$ \\
\hline
\end{tabular}

Note (a): Mean, standard deviation and probability of significance were estimated using SPSS 17.0 based on the factorial scores obtained in SmartPLS 2.0.M3 (Ringle, Wende \& Will, 2005) and the other results were obtained directly in SmartPLS. The values in boldface (in the diagonal) are the square root of the AEV. Correlations greater than or equal to $|0.18|$ were significant at $5 \%$ (two-tailed) and correlations greater than or equal to $|0.23|$ were significant at $1 \%$ (two-tailed). Sample size of 125 cases.

Note (b): Dummy scale (Yes $=1$, No $=0)$.

Legend: $\mathrm{AEV}=$ average extracted variance. C.R. = compound reliability. S.D. $=$ standard deviation.

\subsection{Artifacts}

All the attributes had a larger percentage of responses in the fourth option (artifact is known, made avaialable and utilized). Table 4 presents the distribution of the responses for each artifact.

Table 4: Frequencies of knowledge and use of the artifacts

\begin{tabular}{|c|c|c|c|c|c|c|c|c|c|c|c|}
\hline \multirow{2}{*}{$\begin{array}{l}\text { Attributes } \\
\text { Formal strategic } \\
\text { planning }\end{array}$} & \multicolumn{2}{|c|}{ 0 - Not known } & \multicolumn{2}{|c|}{1 - Known } & \multicolumn{2}{|c|}{$\begin{array}{c}2-\text { Known and } \\
\text { available }\end{array}$} & \multicolumn{2}{|c|}{$\begin{array}{c}3-\text { Known, } \\
\text { avaialable and } \\
\text { utilized }\end{array}$} & \multirow{2}{*}{$\begin{array}{c}\text { Median } \\
3\end{array}$} & \multirow{2}{*}{$\begin{array}{c}\text { Mean } \\
2.4\end{array}$} & \multirow{2}{*}{$\begin{array}{r}\text { S.D. } \\
0.98\end{array}$} \\
\hline & 9 & $7 \%$ & 18 & $14 \%$ & 15 & $12 \%$ & 83 & $66 \%$ & & & \\
\hline $\begin{array}{l}\text { Traditional } \\
\text { annual budgeting }\end{array}$ & 6 & $5 \%$ & 8 & $6 \%$ & 4 & $3 \%$ & 107 & $86 \%$ & 3 & 2.7 & 0.80 \\
\hline $\begin{array}{l}\text { Rolling } \\
\text { forecasting }\end{array}$ & 44 & $35 \%$ & 28 & $22 \%$ & 8 & $6 \%$ & 45 & $36 \%$ & 1 & 1.4 & 1.30 \\
\hline Capital budgeting & 9 & $7 \%$ & 16 & $13 \%$ & 11 & $9 \%$ & 89 & $71 \%$ & 3 & 2.4 & 0.97 \\
\hline $\begin{array}{l}\text { Analysis of } \\
\text { profitability of } \\
\text { products, } \\
\text { customers and } \\
\text { markets }\end{array}$ & 22 & $18 \%$ & 11 & $9 \%$ & 6 & $5 \%$ & 85 & $68 \%$ & 3 & 2.2 & 1.20 \\
\hline $\begin{array}{l}\text { Real options to } \\
\text { analyze } \\
\text { investment } \\
\text { projects }\end{array}$ & 37 & $30 \%$ & 23 & $18 \%$ & 10 & $8 \%$ & 55 & $44 \%$ & 2 & 1.7 & 1.31 \\
\hline
\end{tabular}




\subsection{Attributes as antecedents of the artifacts}

In this step of the analysis we estimated a model in which the four attributes were predictors of the six artifacts. The PLS-PM enabled estimation of all the coefficients simultaneously. We estimated this model four times: complete sample (125 firms), sample with narrow scope (30 firms), intermediate scope (59 firms) and broad scope (36 firms).

The justification for this procedure is that if we had considered the latent variable scope to have a score that increased as it became broader, as Chenhall \& Morris (1986) did, it would have been sufficient to analyze the full sample. However, we observed that the responses to the scope items did not follow this logic, but rather presented organizations that indicated extreme scope and information about the future, but did not indicate the other items.

The criterion used to classify the firms was the following: those with systems providing external information and information about the future (projections) were classified as having broad scope, while those only having external information were classified as having intermediate scope and the others were classified as having narrow scope.

In this respect, the sample size affected the study, because only the intermediate scope had a relevant number of respondents (practically half the sample). In any event, the explanatory power, in the classification of Cohen (1977), was medium in most of the analyses, which is very relevant for this type of study. For the social and behavioral sciences area, Cohen suggests $\mathrm{R}^{2}=2 \%$ for classification as small, $\mathrm{R}^{2}=13 \%$ as medium and $\mathrm{R}^{2}=26 \%$ as large.

To allow understanding the results of the survey, Table 5 presents the information of each artifact broken down into each of the types of scope, after which we comment on the significant effects $(\mathrm{p}<0.05) \mathrm{a}$.

Table 5: Attributes as antecedents of the artifacts

\begin{tabular}{l|c|c|c|c|c|c|c|c}
\hline Dependent variable & \multicolumn{4}{|c}{ Strategic planning } & \multicolumn{4}{c}{ Budgeting } \\
\hline \multicolumn{1}{c|}{ Sample } & All & Broad & Medium & Restrict & All & Broad & Medium & Restrict \\
\hline Agregation & 0,088 & 0,245 & 0,202 & $-0,078$ & 0,042 & 0,060 & 0,147 & $-0,151$ \\
\hline Scope & $\mathbf{0 , 3 0 9 * * *}$ & $\mathbf{0 , 4 2 1} * * *$ & $\mathbf{0 , 2 6 5} * *$ & $\mathbf{0 , 5 4 6} * * *$ & $\mathbf{0 , 1 9 8} *$ & $\mathbf{0 , 3 6 9} * *$ & 0,115 & $\mathbf{0 , 3 9 0} *$ \\
\hline Integration & 0,123 & $\mathbf{0 , 3 2 0} * *$ & 0,103 & 0,196 & $-0,021$ & 0,268 & 0,187 & $-0,155$ \\
\hline Timeliness & 0,037 & $\mathbf{- 0 , 3 4 9} * *$ & 0,203 & $\mathbf{- 0 , 3 8 5 * *}$ & 0,069 & $\mathbf{- 0 , 2 9 7 *}$ & 0,132 & $-0,016$ \\
\hline $\mathrm{R}^{2}$ & $18 \%$ & $36 \%$ & $20 \%$ & $36 \%$ & $6 \%$ & $26 \%$ & $11 \%$ & $15 \%$ \\
\hline
\end{tabular}




\begin{tabular}{l|c|c|c|c|c|c|c|c}
\hline Dependent variable & \multicolumn{4}{|c|}{ Rolling Forecast } & \multicolumn{4}{c}{ Capital Budget } \\
\hline \multicolumn{1}{c|}{ Sample } & All & Broad & Medium & Restrict & All & Broad & Medium & Restrict \\
\hline Agregation & 0,116 & 0,112 & $\mathbf{0 , 3 0 0 * *}$ & $-0,214$ & 0,026 & $-0,004$ & 0,093 & $-0,042$ \\
\hline Scope & 0,029 & 0,176 & 0,014 & $-0,088$ & $\mathbf{0 , 4 0 2} * * *$ & $\mathbf{0 , 3 8 2} * *$ & 0,064 & $\mathbf{0 , 5 0 6 * *}$ \\
\hline Integration & $\mathbf{0 , 2 0 6 * *}$ & $\mathbf{0 , 4 0 2} * *$ & $-0,106$ & 0,077 & $-0,034$ & $\mathbf{0 , 3 9 7} * *$ & $-0,006$ & $-0,148$ \\
\hline Timeliness & 0,104 & 0,267 & $\mathbf{0 , 2 8 1} * *$ & $-0,178$ & 0,127 & $-0,186$ & $\mathbf{0 , 2 7 2} * *$ & $-0,145$ \\
\hline $\mathrm{R}^{2}$ & $100 \%$ & $23 \%$ & $17 \%$ & $12 \%$ & $20 \%$ & $29 \%$ & $9 \%$ & $20 \%$ \\
\hline
\end{tabular}

\begin{tabular}{l|c|c|c|c|c|c|c|c}
\hline Dependent variable & \multicolumn{4}{c|}{ Profitability analysis } & \multicolumn{4}{c}{ Real Options } \\
\hline \multicolumn{1}{c}{ Sample } & All & Broad & Medium & Restrict & All & Broad & Medium & Restrict \\
\hline Agregation & 0,121 & 0,009 & $\mathbf{0 , 2 4 5}^{*}$ & 0,029 & $\mathbf{0 , 2 1 3}^{* *}$ & 0,135 & $\mathbf{0 , 3 4 1 * * *}$ & 0,022 \\
\hline Scope & 0,138 & $\mathbf{- 0 , 2 5 8} *$ & 0,189 & 0,043 & 0,163 & 0,160 & 0,186 & 0,259 \\
\hline Integration & $\mathbf{0 , 3 1 6 * * *}$ & $\mathbf{0 , 2 7 4} *$ & $\mathbf{0 , 2 3 1 *}$ & $\mathbf{0 , 4 9 9} * * *$ & 0,087 & 0,230 & 0,064 & $-0,178$ \\
\hline Timeliness & $\mathbf{- 0 , 1 9 4} * * *$ & $\mathbf{- 0 , 3 1 5 *}$ & $-0,137$ & $-0,220$ & 0,037 & 0,086 & 0,100 & 0,030 \\
\hline $\mathrm{R}^{2}$ & $100 \%$ & $23 \%$ & $17 \%$ & $12 \%$ & $20 \%$ & $29 \%$ & $9 \%$ & $20 \%$ \\
\hline
\end{tabular}

Legend: $* \mathrm{p}<0.10$, two-tailed. $* * \mathrm{p}<0.05$, two-tailed. $* * * \mathrm{p}<0.01$, two-tailed.

Broad $=36$ firms. Intremedate $=59$. Narrow $=30$.

\subsubsection{Aggregation as an antecedent}

In the analysis of the full sample, aggregation had a significant effect only regarding real options, in the total sample and the intermediate scope. Real options analysis is a financial technique applied to the evaluation and management of projects. It provides a perspective that allows analysis, approval and management of projects more closely so as to mitigate risks. It is thus related to the existence of capital budgeting and project management as its antecedents, depending less on scope. It is a tool that can be utilized both for planning and monitoring capital expenditure projects.

In limited form (only in the intermediate scope, not the whole sample), aggregation had a significant affect in relation to rolling forecasting. An analogy can be made with real options in the sense that this artifact is related directly with another (in this case budgeting), of which it is a more sophisticated version.

\subsubsection{Scope as an antecedent}

Scope was relevant as an antecedent in strategic planning and capital budgeting regarding the whole sample. In turn, scope was relevant in annual budgeting only for the broad scope profile.

Regarding strategic planning, as expected scope was more relevant in all the profiles, in the broad profile by definition, and consequently for the implementation of the 
instrument, since to have information about future possibilities to permit the decision process, strategic planning is essential. In the narrow profile, given the absence of specification of information projected for the future, strategic planning was not relevant (indeed it was absent). The breakdown of the variables related to scope showed that (i) demand for historic information, which continued being relevant for the existence of future information, (ii) demand for future information and (iii) demand for external information were the most relevant latent variables associated with the existence of strategic planning.

Scope was also relevant to capital budgeting, an instrument with long-term temporal amplitude and that must be materialized both in strategic planning and annual budgeting, both for the total sample and intermediate and narrow samples. The comments on this point are analogous to those for strategic planning.

Finally, scope was relevant to annual budgeting only in the intermediate and narrow profiles, not for the total sample.

\subsubsection{Integration as an antecedent}

Integration presented a significant effect as a forerunner in the total sample for running forecasting and profitability analysis. With respect to the profiles, it was only relevant for strategic planning and capital budgeting (both with broad profile).

Rolling forecasting is a planning support instrument, specifically for continual updating of the budget. The standout attribute associated with the existence of rolling forecasting in the broad profile was integration among areas, based on the existence of transfer prices, analyses of sub-units, etc., which are relevant to the theme.

In turn, analysis of the profitability of products, customers and markets is an artifact that can be utilized in planning, but it requires obtaining historic budgeting data to be able to understand, assess and redirect actions. The detailing by the information system is fundamental for it to be operationalized for planning and monitoring, explaining the relevance of integration.

In turn, strategic planning and capital budgeting indicated the relevance of the integration attribute in the broad profile. This makes sense because in larger and more complex organizations, having mechanisms such as transfer prices and analysis of subunits is essential for the process to be consolidated. 


\subsubsection{Timeliness as an antecedent}

Timeliness showed an impact in the total sample only related to profitability analysis. In the analysis of the scope profile, strategic planning (broad scope) and capital budgeting (intermediate scope) also were relevant for this attribute in terms of antecedents. The availability of computerized data and the frequency of reports were the most important elements reported by the respondents that influence timeliness in the analysis of profitability. In other words, for the reports to exist, the structure must be avaialable in line with the organization's demand.

In the broad profile, strategic planning as well as annual budgeting rely on the existence of computerized and rapidly available standardized reports, impacting the development of the artifact. This finding demonstrates once again that the demand for high-quality accounting not only involves the ability to consult past information, but also to obtain information to aid decisions about the future.

\section{CONCLUSIONS}

The analysis in this article demonstrated that the attributes of the management information system, for the sample considered, have different scope profiles, with different configurations of relevance in the associations of the attributes. It can be said that the structuring of the management control system involves prior specification of its attributes, and the development of these attributes indicate their influence as antecedents.

It also showed that the attributes interfere in different ways with the artifacts specified, with scope more strongly affecting the broader planning instruments (strategic planning and capital budgeting), which are mainly characterized by decisions. Integration influences the adoption of rolling forecasting, an auxiliary instrument to the more structured and rigid budgeting instrument. Timeliness proved relevant as a factor limiting strategic planning, inhibiting it in the broad scope and in analysis of profitability. In turn, aggregation affects the availability of the real options instrument, a mechanism to help in the analysis of projects. In summary, the greater the complexity and dependence the antecedent artifacts are for implementation of the management control system, the less relevant scope become and the more relevant the other attributes become. This implies, for example, the need for investments in the structure of information systems and in knowledge, based on careful planning. 
In today's competitive environment, it is necessary to analyze and identify the priorities regarding demand for artifacts. In this scenario, important and sudden changes in the macro-environment require adjustments so that management of firms can develop adequately. This means to say that in some organizations the unavailability of artifacts results from the lack of a discussion about infrastructure preceding the implementation of a particular artifact.

Changes in the level of demand for information require repositioning of management information systems and adjustments in their qualitative logic (their attributes). Depending on the system's stage of demand, the attributes are adjusted, and a vicious circle (which could be virtuous) can develop, in which case information is not provided or properly enhanced.

Because Brazilian firms with publicly traded shares are more pressured to provide information than are private firms, the demands for information are different, as are the impacts on the results. Therefore, the main contribution of this work is to allow managers to understand the consequences of changes in the profile of needs of the firm and to carry out the pertinent adjustments in the information systems, irrespective of the direction of the change.

\section{REFERENCES}

AGUIAR, A. B.; FREZATTI, F. Escolha da estrutura apropriada de um sistema de controle gerencial: uma proposta de análise. Revista de Educação e Pesquisa em Contabilidade, v.1, n.3, p.21-44, 2007.

ANTHONY, R. N.; GOVINDARAJAN, V. Sistemas de controle gerencial. São Paulo: Atlas, 2002.

BERRY, A. J.; BROADBENT, J.; OTLEY, D. Management control: theories, issues and performance. 2 ed. New York: Palgrave Macmillan, 2005.

BNDES; circular 64/2002 de 14 de janeiro de 2002. Dispõe sobre porte das empresas.

BOUWENS, J.; ABERNETHY, M. A. The consequences of customization on management accounting system design. Accounting, Organizations and Society, v.25, n.3, p.221-241, 2000.

CHENHALL, R. H. Management control systems design within its organizational context: findings from contingency-based research and directions for the future. Accounting, Organizations and Society, v.28, n.2-3, p.127-168, 2003. 
CHENHALL, R. H.; LANGFIELD-SMITH, K. The relation between strategic priorities, management techniques and management accounting: an empirical investigation using a systems approach. Accounting, Organizations and Society, v.23, n.3, 243-264., 1998.

CHENHALL, R. H.; MORRIS, D. The impact of structure, environment, and interdependence on the perceived usefulness of management accounting systems. The Accounting Review, v.61, n.1, p.16-35, 1986.

COHEN, J. Statistical Power Analysis for the Behavioral Sciences. (Revised Edition). New York: Academic Press, 1977.

DELONE, W. H.; MCLEAN, E. R. Information systems success: the quest for the dependent variable. Information Systems Research, v.3, n.1, p.60-95, 1992.

FERREIRA, A.; OTLEY, D. The design and use of management control systems: An Extended Framework for Analysis, American Accounting Association. Annual Meeting, 2006.

FERREIRA, A.; OTLEY, D. The design and use of performance management systems: An extended framework for analysis. Management Accounting Research, v.20, n.4, p.263282, dec. 2009.

FORNELL, C.; LARCKER, D. F. Evaluating structural equation models with unobservable variables and measurement error. Journal of Marketing Research, v.18, p.39-50, Feb.1981.

FREZATTI, F.; ROCHA, W.; NASCIMENTO, A. R.; JUNQUEIRA, E. Controle gerencial. São Paulo: Atlas, 2009

HANSEN D. R., MOWEN M. M. Management accounting. $7^{\text {th }}$ ed. Mason: Thomson, 1997.

HANSEN, A.; MOURITSEN, J. Management Accounting and changing operations management. In: HOPPER, T.; SCAPENS, R. W.; NORTHCOTT, D. (Ed.). Issues in management Accounting. $3^{\text {rd }}$ edition. London: Prentice-Hall, 2007.

HENRI, J. Organizational culture and performance measurement systems. Accounting, Organizations and Society, v.31, p.77-103, 2006.

IIVARI, J. An Empirical Test of the DeLone-McLean Model of Information System Success. Database for Advances in Information Systems, v.36, n.2, p.8-27, 2005.

MERCHANT, K. A. The design of the corporate budgeting system: influences on managerial behavior and performance. The Accounting Review, v.LVI, n. 4, p.813-829, 1981.

MERCHANT, K. A Modern management control systems: text and cases. New Jersey: Prentice Hall, 1997.

MOORES, K.; YUEN, S. Management accounting systems and organizational configuration: a life-cycle perspective. Accounting, Organizations and Society, v.26, n.4-5, p.351-389, 2001. 
OTLEY, D. Performance management: a framework for management system research. Management Accounting Research, v.10, n.4, p.363-383, 1999.

RINGLE, C.M.; WENDE, S.; WILL, A. SmartPLS 2.0 M3 (beta). Germany: University of Hamburg, 2005. Disponível em: <http://www.smartpls.de>. Acesso em: 05.08.2011.

SCOTT, W. R. Institutions and organizations. Thousands Oaks: Sage, 2001.

SEDDON, P. B. A. Respecification and Extension of the DeLone and McLean Model of IS Success. Information Systems Research, p. 240-253, 1997.

SILVOLA, H. Do organizational life-cycle and venture capital investors affect the management control systems used by the firm? Advances in Accounting, v.24, n.1, p.128-138, 2008.

SIMONS, R. The Role of Management Control Systems in Creating Competitive Advantage: New Perspectives. Accounting, Organizations and Society, 15, p. 127-143, 1990.

SIMONS, R. Levers of control. Boston: Harvard Business School Press, 1995.

ZWICKER, Ronaldo; SOUZA, César Alexandre; BIDO, Diógenes de Souza. Uma revisão do Modelo do Grau de Informatização de Empresas: novas propostas de estimação e modelagem usando PLS (partial least squares). XXXII ENCONTRO DA ASSOCIAÇÃO DOS PROGRAMAS DE PÓS-GRADUAÇÃO E PESQUISA EM ADMINISTRAÇÃO, Anais... Rio de Janeiro: ANPAD, 2008. 